\title{
Petrology and Geochemical Characteristic of the Younger Gabbros of Wadi Shianite Area, Southeastern Desert, Egypt
}

\author{
Magdy S. Basta \\ Faculty of Petroleum and Mining Engineering, Sues University, Sues, Egypt \\ Email: magdybasta2010@yahoo.com \\ Received 16 June 2015; accepted 25 August 2015; published 28 August 2015 \\ Copyright (C) 2015 by author and Scientific Research Publishing Inc. \\ This work is licensed under the Creative Commons Attribution International License (CC BY). \\ http://creativecommons.org/licenses/by/4.0/ \\ (c) (i) Open Access
}

\begin{abstract}
The present work is a petrological study of the gabbroic rocks of wadi Shianite Southeastern Desert of Egypt. Chemical analyses for major and trace elements showed that there are 3 main gabbro types. These are: 1) pyroxene hornblende gabbronorite; 2) hornblende gabbro; and 3) anorthosite. The opaque minerals study of the gabbroic rocks showed that they composed mainly of ilmenite, magnetite and sulphides. The present gabbroic rocks work are related to calc-alkaline magma type, similar to the younger gabbros in other areas in the Eastern Desert.
\end{abstract}

\section{Keywords}

Pyroxene Hornblende Gabbronorite, Hornblende Gabbro and Anorthosite

\section{Introduction}

The gabbroic rocks represent major rock units in the Pre-Cambrian shield. Several studies were carried out dealing with the general geology and the petrology of these rocks. Recent studies indicated two types of gabbros, older gabbros (Takla 1971 [1], Basta and Takla 1974 [2], Takla et al., 1981 [3] and Ghoneim et al. 1991 [4]), or metagabbro (Akaad and Neweir, 1980 [5], and Mansi, 1996 [6]), and younger gabbros (Takla 1971 [1], Ghoneim et al. 1991 [4]) Mohamed \& Hassanen (1996) [7] El Gaby et al., (1988) [8] referred the older metagabbro of the Pan African belt in Egypt as member of the ophiolite sequence and have a tholeiitic composition. They considered the metagabbros as belonging to the weakly metamorphosed calc-alkaline island arc rocks. They could be intruded after the over thrusting of the younger metavolcanics.

El Gaby et al. (op. sit), classified the younger gabbros as intrusive, mantle derived rocks composed commonly of fresh peridotites, gabbro diorite and intruded at the late Cordilleran stage (655 - $570 \mathrm{Ma}$ ). The present work 
deals with the petrological and mineral chemistry to identify and detect the magma type and tectonic setting of the younger gabbroic rocks of Wadi Shianite.

\section{General Geology and Petrography}

The studied area is located between longitude $34^{\circ} 15^{\prime}-34^{\circ} 25^{\prime} \mathrm{E}$ and latitude $23^{\circ} 00^{\prime}-23^{\circ} 10^{\prime} \mathrm{N}$. It covers by Precambrian rocks represented by massive granodiorite, deformed granodiorite, younger gabbro, hornblende granite, and perthitic leucogranite (Figure 1).

The exposed late neoproterozoic rocks in the study area are classified according to Takla (2002) [9] into:

\section{V-Intraplate Magmatism and Sediments Youngest}

c) perthitic leucogranites

b) hornblend granites

a) younger gabbro

\section{VI-Subduction-Related Granitoids (Arc Granites)}

b) deformed granodiorites

a) massive granodiorites

Intraplate Magmatism and Sediments. The younger gabbros form arched outcrop within the hornblende monzogranite and separated from them by wadi alluvium. They form low hills with gentle slope (Figure 1). These rocks are homogenous in composition usually massive and have characteristic boulder-shape weathering at the outer parts. These gabbros are slightly fractured and they classified into: 1) pyroxene hornblende gabbronorite; 2) hornblende gabbro and 3) anorthosite. The modal composition of these gabbros are given in Table 1 and graphically represented on plagioclase-pyroxene-hornblende diagram (Streckeisen, 1976) [10]. On this diagram (Figure 2) the studied gabbroic rocks plot within the pyroxene hornblende gabbro norite, hornblende gabbro and anorthosite fields. The pyroxene hornblende gabbronorite composed mainly of plagioclase, orthoand clino-pyroxene, hornblende and opaques. The plagioclases $\left(\mathrm{An}_{50-65}\right)$, are euhedral prismatic crystal (Plate I(a)) generally fresh, twinned according to albite pericline, and Carlsbad laws (Plate I(b)). Sometimes plagioclase crystals are partially sericitized especially at the contact with the hornblende granites. The clino-pyroxene represented by titanaugite and hypersthene. The augite occurs as anhedral basal section and short prisms (Plate $I(c)$ ), while hypersthene occurs as subhedral to anhedral crystals (Plat $I(d)$ ) strong pleochroic from pale green to pale brown. The hornblende gabbro is coarse- to medium-grained, orthocumulate, composed essentially of plagioclase as cumulate phase enclosed in intercumulus hornblende and biotite (Plate I(e)), opaque, titanite and apatite are accessories and quartz is secondary mineral constituent.

The anorthosite composed mainly plagioclase $\left(\mathrm{An}_{50-65}\right)$ as the cumulus phase together with small amount of

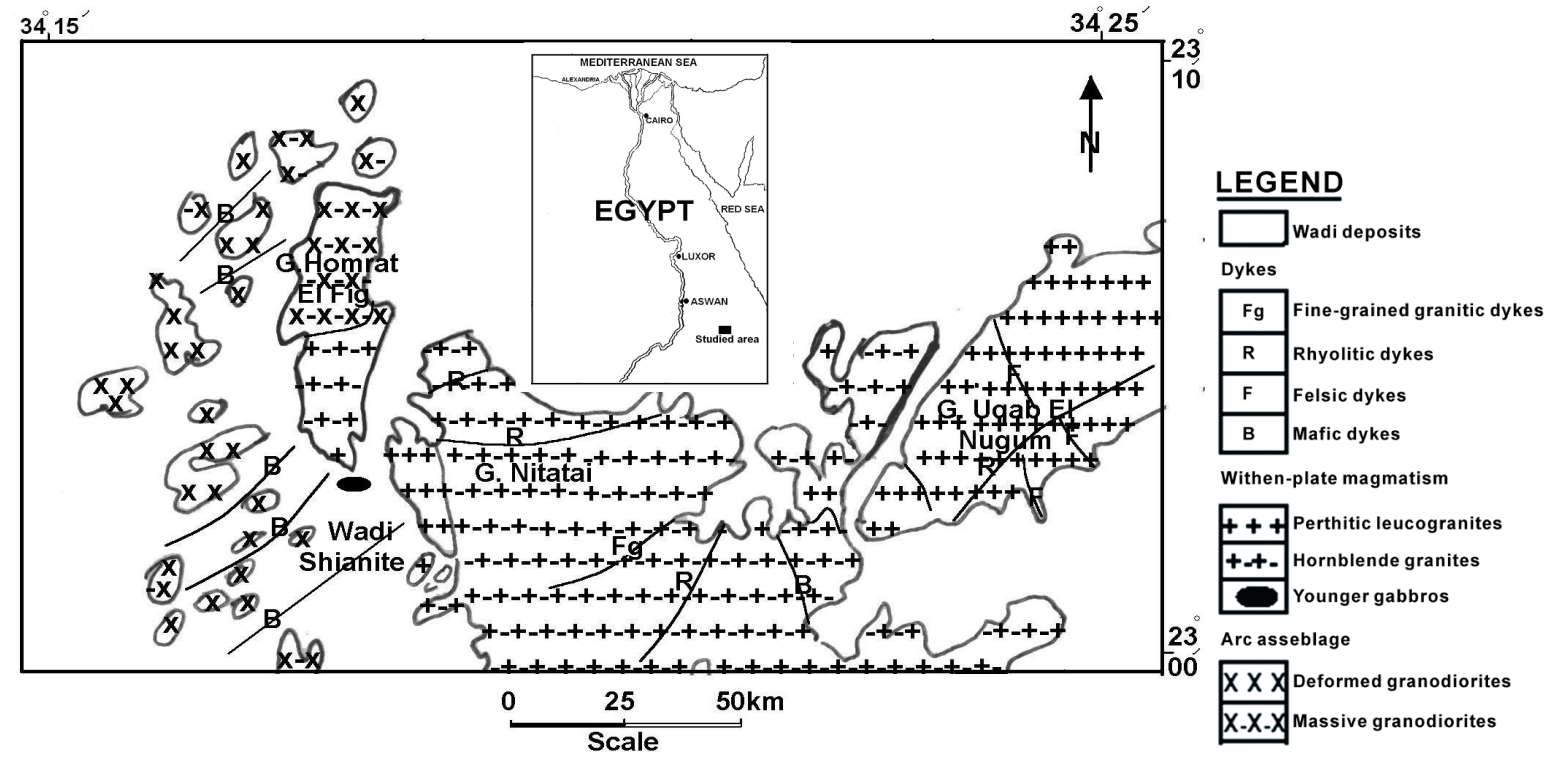

Figure 1. Lithlogical map of Wadi Shianit area, South Eastern Desert, Egypt. 

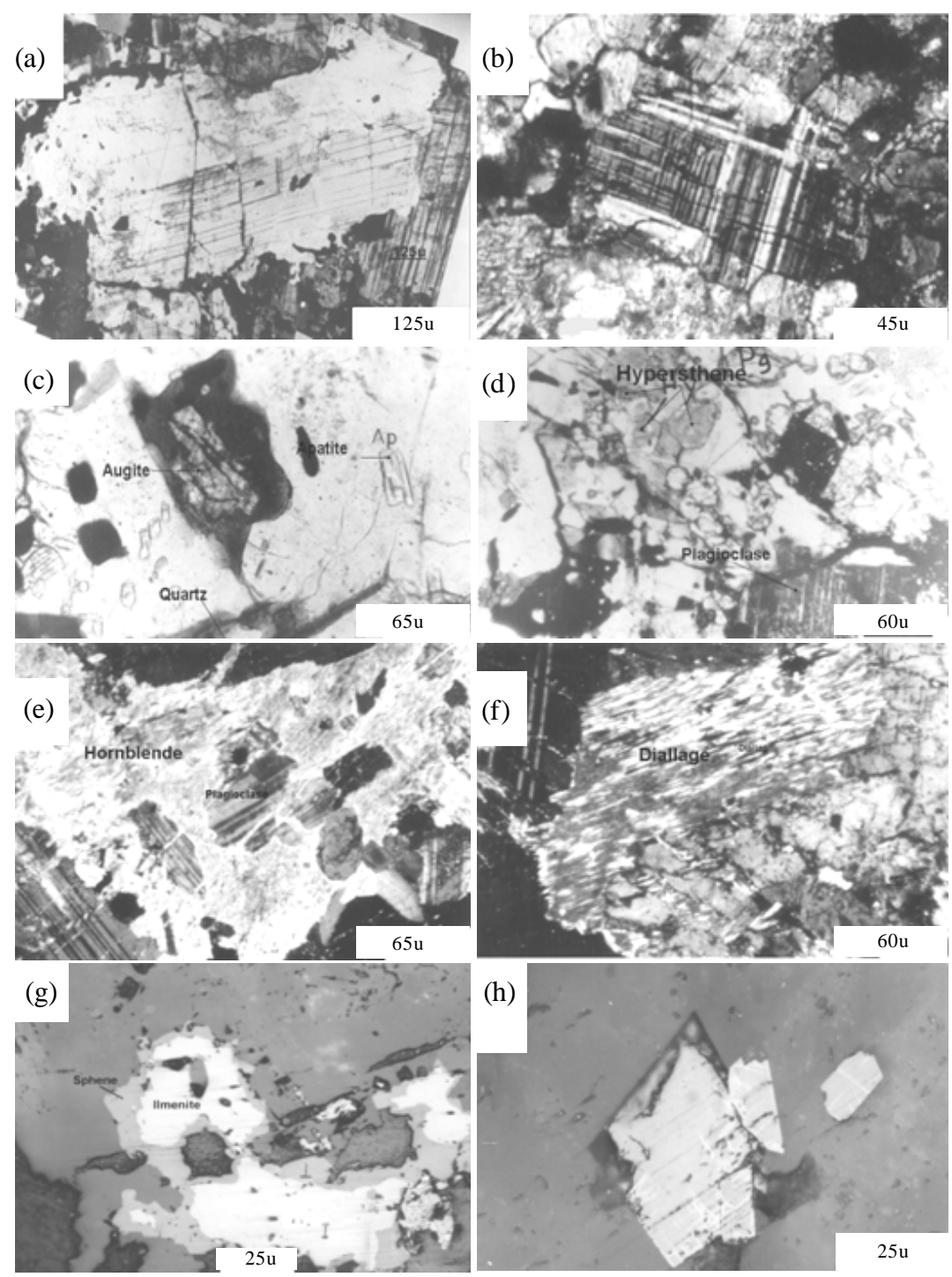

Plate I. (a) Euhedral prismatic plagioclase C.N.; (b) pericline twining in plagioclase C.N.; (c) short prism augite crystal PPL; (d) hypersthene crystal C.N.; (e) cumulus plagioclase enclosed in intercumulus hornblende C.N.; (f) diallage crystal as intercumulus C.N.; (g) ilmenite grain replaced by titanite along peripheries; and (h) pyrite inclusion in ilmenite are extensively to completely replaced by gothite.

Table 1. Mineral composition for the younger gabbros of Wadi Shianite area.

\begin{tabular}{|c|c|c|c|c|c|c|c|c|c|c|c|c|}
\hline \multirow{2}{*}{$\begin{array}{l}\text { Rock types } \\
\text { Sample No. }\end{array}$} & \multicolumn{4}{|c|}{ Pyroxene hornblende gabbronorite } & \multicolumn{4}{|c|}{ Hornblende gabbro } & \multicolumn{4}{|c|}{ Anorthosite } \\
\hline & 1 & 2 & 3 & 4 & 5 & 6 & 7 & 8 & 9 & 10 & 11 & 12 \\
\hline Plagioclase & 55 & 51 & 52 & 53 & 55 & 58 & 48 & 56 & 88 & 85 & 90 & 89 \\
\hline $\begin{array}{c}\text { Brown } \\
\text { hornblende }\end{array}$ & 7 & 12 & 11 & 10 & 36 & 28 & 34 & 33 & 1 & 0.5 & 1.5 & 1 \\
\hline Clino-pyroxene & 19 & 20 & 17 & 19 & -- & -- & 3 & 1 & 7 & 10 & 4 & 7 \\
\hline Orth-pyroxene & 8 & 5 & 9 & 8 & -- & -- & -- & -- & -- & -- & -- & -- \\
\hline Opaques & 4 & 3 & 3 & 3 & 4 & 6 & 11 & 7 & 2 & 4 & 1 & 1 \\
\hline Accessory & 2 & 3 & 3 & 2 & 1 & 2 & 1 & 2 & 1 & 1 & 1 & 1 \\
\hline Quartz $^{*}$ & 5 & 6 & 3 & 5 & 6 & 6 & 3 & 4 & 2 & -- & 3 & 1 \\
\hline
\end{tabular}

*Secondary quartz. 


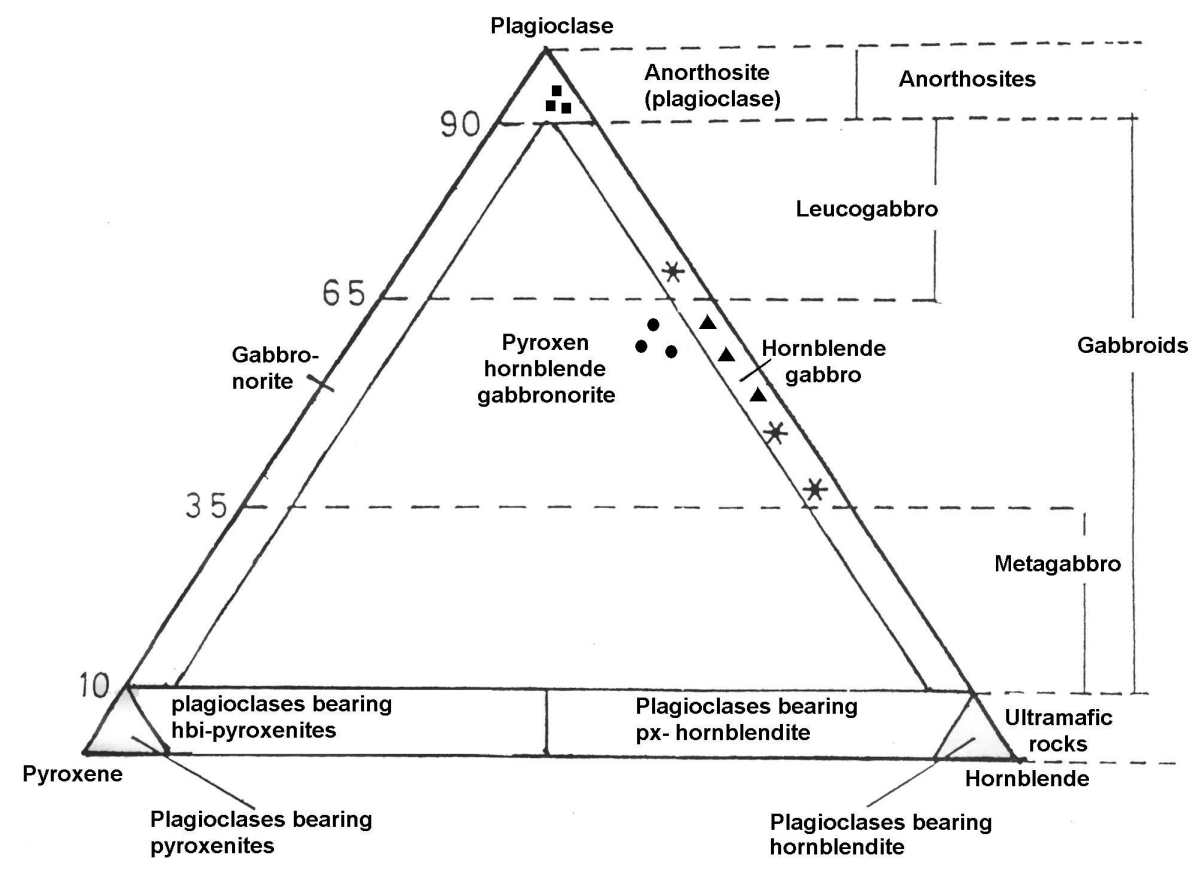

Figure 2. Modal plagioclase-pyroxene-hornblende diagram for younger gabbros (Streckeisen, 1976). $\Delta$ hornblende gabbros, pyroxene hornblende, $\square$ gabbronorite anorthosite.

diallage as the intercumulus phase (Plate I(f)). The opaque minerals in the studied younger gabbros are mainly represented by ilmenite, magnetite and sulphides. The ilmenite is subhedral homogenous prismatic fresh crystals, sometimes replaced by titanite along grain peripheries (Plate I(g)). Magnetite occurs as discrete subhedral to euhedral grains slightly martitized along (111) plane. Sulphides occur in very small amount as pyrite and pyrrhotite inclusions. Pyrite inclusions in ilmenite are extensively to completely replaced by goethite (Plate I(h)).

Subduction-Related Granitoids (Arc Granites), represented by massive granodiorite and deformed granodiorite. The massive granodiorite rocks occupy as few masses in the central part (Figure 1). They are massive and less weathered, grayish green to green color and cut by acidic dykes and quartz veins.

Under the microscope, They are coarse- to medium-grained, composed of plagioclase $\left(\mathrm{An}_{20}-\mathrm{An}_{27}\right)$, potash feldspar and hornblende as essential minerals. Accessory minerals represented by quartz, biotite, sphene, rutile, apatite, zircon and opaque minerals. Calcite, chlorite and saussurite are the main secondary minerals. The textures of the massive granodiorites are holocrystalline, The porphyritic textures. Hypidiomorphic and granular textures are also recorded.

The deformed granodiorites occur in the eastern part of the study area along Gebal Shianite (Figure 1). These rocks form high hills cutting by acidic dykes. The deformed granodiorites are fine to medium-grained rocks that are highly weathered to boulders (Plate I(f)) and show exfoliation structure.

Under the microscope, they are composed of plagioclase $\left(\mathrm{An}_{18-22}\right)$, showing percline twining. Alkali feldspar (orthoclase and microcline), quartz (undulatory extinction) are the essential minerals. Biotite, muscovite, sphene, zircon, apatite and opaque minerals are the accessory minerals. Chlorite, saussurite and clay minerals are found as secondary minerals. The granodiorites are holocrystalline, porphyritic with hypidiomorphic textures.

\section{Geochemistry of the Younger Gabbros}

Five samples were analyzed for major oxides and trace elements analyses and two samples for rear earth element (REEs) analyses of the studied younger gabbros as given in Table 2.

Table 3 shows the average chemical composition of the studied gabbros and similar rocks from different localities in the Eastern Desert of Egypt. From Table 3 it is clear that the pyroxene hornblende gabbronorite is more rich in $\mathrm{SiO}_{2}$ than the other types, while the hornblende gabbro is more rich in $\mathrm{TiO}_{2}$ than the other types. All the types of younger gabbros have similar contents of the other major oxides. From Table 3 it is evident that the pyroxene hornblende gabbronorite of the study area is similar to the younger gabbro of El Bakria (El Mansi, 
Table 2. Major oxides, trace elements, CIPW norms and some REE for the studied younger gabbros of Wadi Shianite area.

\begin{tabular}{|c|c|c|c|c|c|}
\hline \multirow{2}{*}{$\begin{array}{c}\text { Rock types } \\
\text { S. No. }\end{array}$} & Pyroxene hornblende gabbronorite & \multicolumn{3}{|c|}{ Hornblende gabbros } & \multirow{2}{*}{$\begin{array}{c}\text { Anorthosite } \\
5\end{array}$} \\
\hline & 1 & 2 & 3 & 4 & \\
\hline \multicolumn{6}{|c|}{ Major oxides wt\% } \\
\hline $\mathrm{SiO}_{2}$ & 48.91 & 47.01 & 45.89 & 46.98 & 45.99 \\
\hline $\mathrm{TiO}_{2}$ & 00.44 & 01.54 & 00.98 & 01.19 & 00.82 \\
\hline $\mathrm{Al}_{2} \mathrm{O}_{3}$ & 11.92 & 13.05 & 12.52 & 13.81 & 12.11 \\
\hline $\mathrm{Fe}_{2} \mathrm{O}_{3}$ & 05.05 & 04.69 & 05.55 & 05.95 & 05.09 \\
\hline $\mathrm{FeO}$ & 05.03 & 0.520 & 06.01 & 06.58 & 04.93 \\
\hline $\mathrm{MnO}$ & 00.20 & 00.12 & 00.14 & 00.12 & 00.18 \\
\hline $\mathrm{MgO}$ & 11.91 & 14.01 & 13.10 & 13.01 & 13.05 \\
\hline $\mathrm{CaO}$ & 12.51 & 11.20 & 12.05 & 11.80 & 13.55 \\
\hline $\mathrm{Na}_{2} \mathrm{O}$ & 02.05 & 02.43 & 01.90 & 01.70 & 01.94 \\
\hline $\mathrm{K}_{2} \mathrm{O}$ & 00.38 & 00.33 & 00.57 & 00.20 & 00.26 \\
\hline $\mathrm{P}_{2} \mathrm{O}_{5}$ & 0.59 & 0.39 & 00.16 & 00.29 & 00.34 \\
\hline L.O.I & 00.69 & 01.77 & 00.69 & 00.38 & 01.09 \\
\hline Total & 99.77 & 100.71 & 100.44 & 100.11 & 99.91 \\
\hline \multicolumn{6}{|c|}{ Trace elements ppm } \\
\hline $\mathrm{Cr}$ & 172 & 195 & 188 & 379 & 212 \\
\hline $\mathrm{Ni}$ & 175 & 48 & 196 & 201 & 182 \\
\hline Co & 41 & 133 & 45 & 61 & 52 \\
\hline $\mathrm{V}$ & 191 & 130 & 160 & 130 & 150 \\
\hline $\mathrm{Cu}$ & 192 & 54 & 162 & 72 & 53 \\
\hline $\mathrm{Pb}$ & 33 & 26 & 36 & 22 & 27 \\
\hline $\mathrm{Zn}$ & 58 & 63 & 23 & 49 & 51 \\
\hline $\mathrm{Rb}$ & 33 & 29 & 63 & 23 & 29 \\
\hline $\mathrm{Ba}$ & 305 & 204 & 28 & 170 & 255 \\
\hline $\mathrm{Sr}$ & 310 & 290 & 270 & 275 & 240 \\
\hline Ga & 25 & 24 & 285 & 19 & 28 \\
\hline $\mathrm{Nb}$ & 28 & 19 & 17 & 26 & 50 \\
\hline $\mathrm{Hf}$ & 25 & 18 & 25 & 18 & 50 \\
\hline $\mathrm{Zr}$ & 38 & 40 & 25 & 39 & 45 \\
\hline $\mathrm{Y}$ & 10 & 7 & 8 & 6 & 8 \\
\hline U & 3 & 1.8 & 2.1 & 1.2 & 2.5 \\
\hline Th & 7 & 4.2 & 5 & 4 & 6 \\
\hline \multicolumn{6}{|c|}{ REE ppm } \\
\hline $\mathrm{La}$ & & & 4.67 & & 4.6 \\
\hline $\mathrm{Ce}$ & & & 8.72 & & 7.2 \\
\hline $\mathrm{Nd}$ & & & 8.57 & & 7.3 \\
\hline $\mathrm{Sm}$ & & & 2.44 & & 2.4 \\
\hline $\mathrm{Eu}$ & & & 1.3 & & 1.5 \\
\hline Gd & & & 2.9 & & 2.6 \\
\hline $\mathrm{Tb}$ & & & 0.38 & & 0.35 \\
\hline Er & & & 2.3 & & 1.3 \\
\hline $\mathrm{Yb}$ & & & 1.9 & & 1.7 \\
\hline $\mathrm{Lu}$ & & & 0.4 & & 0.29 \\
\hline \multicolumn{6}{|c|}{ CIPW norms } \\
\hline Qz & 01.55 & 02.04 & 01.32 & 02.07 & 02.04 \\
\hline Or & 16.81 & 10.06 & 18.94 & 15.84 & 15.72 \\
\hline $\mathrm{Ab}$ & 31.54 & 27.07 & 30.61 & 26.32 & 29.56 \\
\hline An & 24.92 & 25.12 & 25.53 & 26.36 & 26.82 \\
\hline
\end{tabular}


Table 3. Major oxides of younger gabbro form different localities of Egypt.

\begin{tabular}{cccccccc}
\hline Oxides & 1 & 2 & 3 & 4 & 5 & 6 & 7 \\
\hline $\mathrm{SiO}_{2}$ & 49.2 & 47.25 & 45.60 & 46.12 & 46.72 & 47.58 & 48.34 \\
$\mathrm{TiO}_{2}$ & 00.55 & 01.33 & 00.90 & 01.20 & 00.96 & 00.51 & 0.49 \\
$\mathrm{Al}_{2} \mathrm{O}_{3}$ & 11.90 & 12.37 & 12.10 & 12.71 & 19.42 & 08.39 & 21.43 \\
$\mathrm{Fe}_{2} \mathrm{O}_{3}$ & 05.01 & 05.37 & 05.08 & 05.07 & 02.66 & 02.66 & 01.03 \\
$\mathrm{FeO}$ & 05.20 & 05.93 & 04.94 & 05.14 & 03.14 & 07.99 & 04.21 \\
$\mathrm{MnO}$ & 00.20 & 00.13 & 00.18 & 00.14 & 00.18 & 00.24 & 00.11 \\
$\mathrm{MgO}$ & 11.95 & 13.37 & 13.05 & 12.67 & 12.73 & 20.51 & 07.04 \\
$\mathrm{CaO}$ & 12.50 & 11.68 & 13.55 & 12.67 & 10.12 & 08.03 & 12.47 \\
$\mathrm{Na} 2 \mathrm{O}$ & 02.05 & 02.00 & 01.95 & 01.80 & 01.60 & 00.68 & 01.84 \\
$\mathrm{~K}_{2} \mathrm{O}$ & 00.38 & 00.37 & 00.25 & 00.30 & 00.26 & 00.14 & 00.23 \\
$\mathrm{P}_{2} \mathrm{O}_{5}$ & 00.59 & 00.28 & 00.34 & 00.31 & 00.02 & 00.05 & 00.08 \\
$\mathrm{L.O} . \mathrm{I}$ & 00.69 & 01.28 & 01.08 & 02.00 & 01.66 & 04.21 & 02.22 \\
\hline
\end{tabular}

1: Data of pyroxene hornblende gabbronorite of the studied area. 2: Data of hornblende gabbro of studied area. 3: Data of anorthosite of the studied area. 4: Data after Hamimi (1992) [11]. 5: Data after Takla et al. (1981) [3]. 6: Data after Takla and Neweir (1980) [12]. 7: Data after El Mansi (1996) [6].

1996 [6]), while the hornblende gabbros similar to the younger gabbros of Gabal Ambat and gabbro Akarem (Takla et al., 1981 [3]). The anorthosites of the studied area are similar to the leucogabbro of Wadi Beitan (Hamimi, 1992) [11].

To display the trace elements distribution in the studied gabbros they are plotted on spider diagram normalized to Primitive mantle according to Wood et al., 1975 [13] (Figure 3(a)) shows that the studied gabbros are depleted in $\mathrm{Cr}, \mathrm{Cu}, \mathrm{Zr}$ and $\mathrm{Ni}$ and enriched in the other element. The REE pattern of the studied gabbronorite and anorthosite (Figure 3(b)) are very similar to each other and similar to that of calc-alkaline rocks.

\subsection{Typology}

The studied gabbroic rocks are chemically classified using the following relationships: On the normative Ab-An-Or diagram (Figure 3(c)) according to Streckeisen, (1976) [10], the studied younger gabbros plot in the gabbro diorite field. On the $\left(\mathrm{Na}_{2} \mathrm{O}+\mathrm{K}_{2} \mathrm{O}\right)$ vs. $\mathrm{SiO}_{2}$ diagram (Figure 3(d)) according to Wilson, 1989 [14] all the analyzed rocks plot in the field of gabbro

\subsection{Magam Type}

On the relation between Alk, vs. $\mathrm{SiO}_{2}$ (Figure 3(d)) the gabbros plot in the sub alkaline (calc-alkaline) field. The Same conclusion is reached on plotting the analyses of the studied gabbro on $\mathrm{Zr}$ vs. $\mathrm{P}_{2} \mathrm{O}_{5}$ diagram (Figure 3(e)) according to Winchester and Floyd, 1977 [15], where they plot in sub alkaline field. In the relation between $\mathrm{FeO}$ vs. (FeO*/MgO), according to Miyashiro, 1975 [16] (Figure 3(f)) the younger gabbros plot in the calc-alkaline field. In conclusion the younger gabbro of Wadi Shianite area originated from a calc-alkaline magma source similar to other younger gabbro in different areas in the Eastern Desert of Egypt (Takla et al., 2002) [9].

\subsection{Tectonic Setting}

The tectonic setting of the studied gabbroic rocks can be predicted by using $\mathrm{TiO}_{2}-\mathrm{K}_{2} \mathrm{O}-\mathrm{P}_{2} \mathrm{O}_{5}$ ternary diagram (Pearce et al. 1975) [17]. On this diagram the studied gabbros plot in the continental field (Figure 4).

\subsection{Mineral Chemistry}

\subsubsection{Pyroxene}

The mineral analyses for the clino-pyroxenes are presented in Table 4(a). In relation between $\mathrm{Q}=\mathrm{Ca}+\mathrm{Mg}+$ 


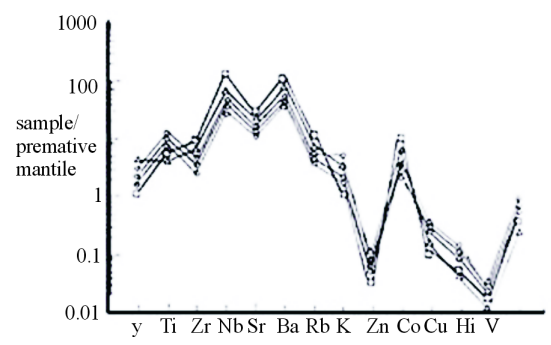

(a)

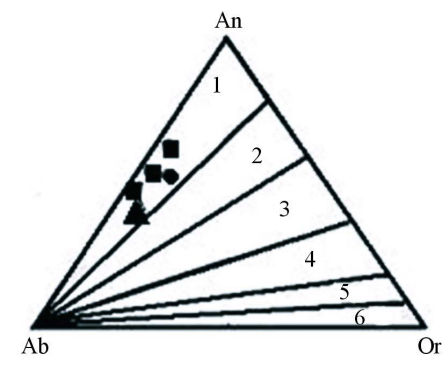

(c)

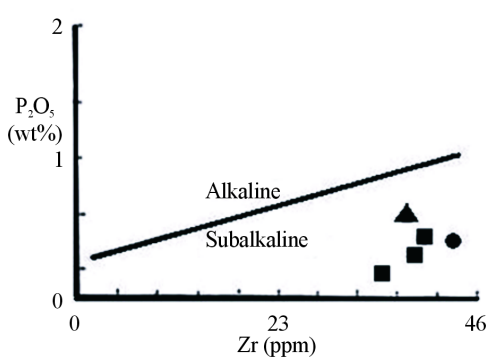

(e)

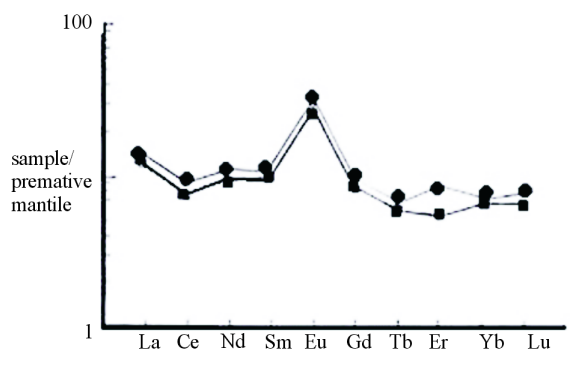

(b)

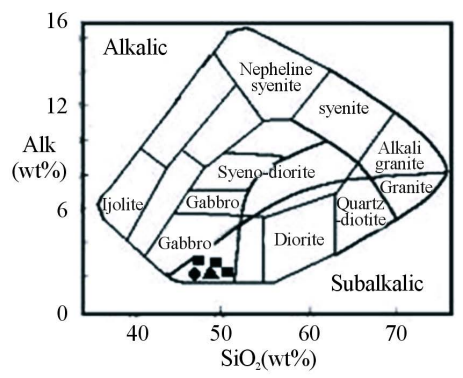

(d)

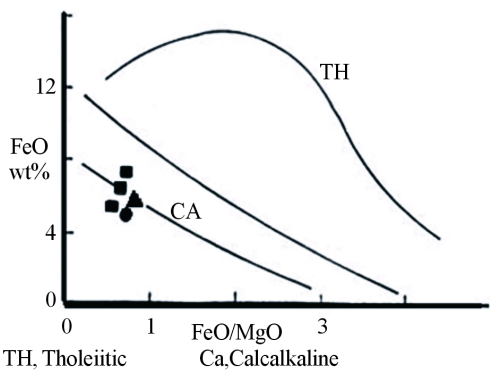

(f)

Figure 3. Geochemical characteristics of the studied younger gabbros from Wadi Shianite area. (a) Spider diagram for trace elements (b) REE pattern (c) Ab-An-Or diagram (Streckeisen, 1976) (d) $\left(\mathrm{Na}_{2} \mathrm{O}+\mathrm{K}_{2} \mathrm{O}\right)$ vs $\mathrm{SiO}_{2}$ (Wilson, 1989) (e) $\mathrm{Zr}_{-} \mathrm{P}_{2} \mathrm{O}_{5}$ diagram (Winchester and Floyd, 1977) (f) FeO/MgO-FeO* diagram (Miyashiro, 1975) (symbols as Figure 2).

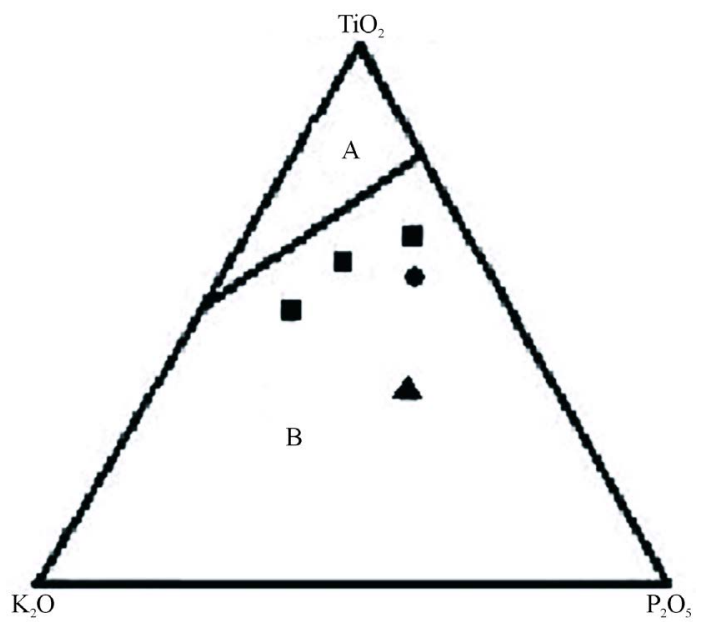

Figure 4. Tectonic discrimination plot for the studied younger gabbros. $\mathrm{TiO}_{2}-\mathrm{K}_{2} \mathrm{O}-\mathrm{P}_{2} \mathrm{O}_{5}$ diagram (Pearce et al. 1975). (A) Oceanic field; (B) continental field (symbols as Figure 2). 
Table 4. Chemical composition and structural formula for (a) clino-pyroxene, (b) hornblende, and (c) plagioclase of the younger gabbros of Wadi Shianit area, South Eastern Desert, Egypt.

(a)

\begin{tabular}{|c|c|c|c|c|c|c|}
\hline Spot No. & 1 & 2 & 3 & 4 & 5 & 6 \\
\hline \multicolumn{7}{|c|}{ Major oxides wt $\%$ recalculated to $100 \%$} \\
\hline $\mathrm{SiO}_{2}$ & 48.16 & 48.68 & 50.42 & 47.54 & 51.01 & 49.92 \\
\hline $\mathrm{TiO}_{2}$ & 0.72 & 0.54 & 0.29 & 0.59 & 0.24 & 0.62 \\
\hline $\mathrm{Al}_{2} \mathrm{O}_{3}$ & 1.06 & 0.78 & 1.58 & 1.79 & 0.94 & 0.92 \\
\hline $\mathrm{FeO} *$ & 27.64 & 22.53 & 23.06 & 28.18 & 25.93 & 23.10 \\
\hline $\mathrm{MnO}$ & 0.12 & 0.59 & 0.52 & 0.81 & 0.24 & 0.64 \\
\hline $\mathrm{MgO}$ & 3.53 & 16.18 & 14.58 & 11.24 & 12.11 & 9.86 \\
\hline $\mathrm{CaO}$ & 18.50 & 9.90 & 9.45 & 9.27 & 9.20 & 14.4 \\
\hline $\mathrm{Na}_{2} \mathrm{O}$ & 0.23 & 0.65 & 0.07 & 0.23 & 0.11 & 0.44 \\
\hline $\mathrm{K}_{2} \mathrm{O}$ & 0.04 & 0.15 & 0.03 & 0.05 & 0.04 & 0.1 \\
\hline Total & 100 & 100 & 100 & 100 & 100 & 100 \\
\hline \multicolumn{7}{|c|}{ Cations on basis of 6 oxygens } \\
\hline $\mathrm{Si}$ & 1.841 & 1.827 & 1.929 & 1.946 & 1.968 & 1.935 \\
\hline $\mathrm{Ti}$ & 0.022 & 0.026 & 0.009 & 0.027 & 0.009 & 0.025 \\
\hline $\mathrm{Al}$ & 0.051 & 0.034 & 0.067 & 0.083 & 0.029 & 0.465 \\
\hline $\mathrm{Al}$ & 0.051 & 0.039 & 0.009 & 0.055 & 0.029 & 0.015 \\
\hline $\mathrm{Al}$ & 0.00 & 0.00 & 0.00 & 0.028 & 0.00 & 0.00 \\
\hline $\mathrm{Fe}$ & 0.915 & 0.615 & 0.713 & 0.888 & 0.030 & 0.602 \\
\hline $\mathrm{Mn}$ & 0.019 & 0.019 & 0.016 & 0.027 & 0.010 & 0.018 \\
\hline $\mathrm{Mg}$ & 0.211 & 0.925 & 1.21 & 0.651 & 0.832 & 0.733 \\
\hline $\mathrm{Ca}$ & 0.826 & 0.417 & 0.095 & 0.362 & 0.858 & 0.526 \\
\hline $\mathrm{Na}$ & 0.017 & 0.048 & 0.004 & 0.018 & 0.035 & 0.024 \\
\hline $\mathrm{K}$ & 0.002 & 0.080 & 0.00 & 0.003 & 0.002 & 0.021 \\
\hline
\end{tabular}

(b)

\begin{tabular}{|c|c|c|c|c|}
\hline Spot No. & 1 & 2 & 3 & 4 \\
\hline \multicolumn{5}{|c|}{ Major oxides wt $\%$ recalculated to $100 \%$} \\
\hline $\mathrm{SiO}_{2}$ & 32.19 & 30.38 & 38.27 & 30.97 \\
\hline $\mathrm{TiO}_{2}$ & 0.011 & 0.002 & 0.18 & 0.002 \\
\hline $\mathrm{Al}_{2} \mathrm{O}_{3}$ & 20.23 & 19.43 & 17.58 & 20.33 \\
\hline $\mathrm{FeO} *$ & 27.15 & 30.12 & 25.22 & 28.34 \\
\hline $\mathrm{MgO}$ & 18.26 & 16.87 & 16.89 & 16.62 \\
\hline $\mathrm{CaO}$ & 0.018 & 0.017 & 0.519 & 0.418 \\
\hline $\mathrm{Na}_{2} \mathrm{O}$ & 2.24 & 3.21 & 1.32 & 3.32 \\
\hline $\mathrm{K}_{2} \mathrm{O}$ & 0.011 & 0.012 & 0.012 & 0.011 \\
\hline Total & 100 & 100 & 100 & 100 \\
\hline \multicolumn{5}{|c|}{ Cations on basis of 32 oxygens } \\
\hline $\mathrm{Si}$ & 4.68 & 4.45 & 5.65 & 4.54 \\
\hline $\mathrm{Ti}$ & 0.011 & 0.01 & 0.389 & 0.011 \\
\hline $\mathrm{Al}$ & 3.07 & 2.97 & 2.539 & 3.12 \\
\hline $\mathrm{Al}$ & 2.05 & 1.98 & 2.009 & 2.74 \\
\hline $\mathrm{Al}$ & 1.05 & 0.98 & 0.531 & 0.48 \\
\hline $\mathrm{Fe}$ & 3.44 & 3.69 & 2.74 & 3.57 \\
\hline $\mathrm{Mg}$ & 3.98 & 3.68 & 1.72 & 3.69 \\
\hline $\mathrm{Ca}$ & 0.001 & 0.001 & 0.08 & 0.07 \\
\hline $\mathrm{Na}$ & 0.64 & 0.91 & 0.38 & 0.95 \\
\hline $\mathrm{K}$ & 0.001 & 0.001 & 0.001 & 0.002 \\
\hline
\end{tabular}


(c)

\begin{tabular}{|c|c|c|c|c|}
\hline Spot No. & 1 & 2 & 3 & 4 \\
\hline \multicolumn{5}{|c|}{ Major oxides wt $\%$ recalculated to $100 \%$} \\
\hline $\mathrm{SiO}_{2}$ & 51.64 & 48.09 & 51.75 & 50.62 \\
\hline $\mathrm{TiO}_{2}$ & 0.04 & 0.00 & 0.04 & 0.03 \\
\hline $\mathrm{Al}_{2} \mathrm{O}_{3}$ & 28.90 & 31.24 & 30.07 & 31.48 \\
\hline $\mathrm{FeO}^{*}$ & 0.47 & 0.27 & 0.38 & 0.45 \\
\hline $\mathrm{MgO}$ & 0.08 & 0.21 & 0.16 & 0.12 \\
\hline $\mathrm{CaO}$ & 13.65 & 16.45 & 13.12 & 12.45 \\
\hline $\mathrm{Na}_{2} \mathrm{O}$ & 5.01 & 3.57 & 4.29 & 4.65 \\
\hline $\mathrm{K}_{2} \mathrm{O}$ & 0.21 & 0.17 & 0.19 & 0.20 \\
\hline Total & 100 & 100 & 100 & 100 \\
\hline \multicolumn{5}{|c|}{ Cations on basis of 8 oxygens } \\
\hline $\mathrm{Si}$ & 9.55 & 8.89 & 9.25 & 9.42 \\
\hline $\mathrm{Al}$ & 6.32 & 6.93 & 0.67 & 6.55 \\
\hline $\mathrm{Fe}$ & 0.079 & 0.047 & 0.083 & 0.031 \\
\hline $\mathrm{Mg}$ & 0.072 & 0.085 & 0.099 & 0.051 \\
\hline $\mathrm{Ca}$ & 1.476 & 0.953 & 1.47 & 1.50 \\
\hline $\mathrm{Na}$ & 2.37 & 3.32 & 2.64 & 2.68 \\
\hline K & 0.039 & 0.04 & 0.035 & 0.027 \\
\hline An & 62.45 & 72.72 & 69.28 & 65.70 \\
\hline $\mathrm{Ab}$ & 36.30 & 21.99 & 29.58 & 33.10 \\
\hline Or & 1.24 & 0.96 & 1.13 & 1.70 \\
\hline
\end{tabular}

$\mathrm{FeO}$ and $\mathrm{J}=2 \mathrm{Na}$ (plot Figure 5(a)) according to Morimoto et al. (1988) [18], the data plot at Q + J between 1.5 - 2.00. In the $\mathrm{CaSiO}_{3}$ (Wo), $\mathrm{MgSiO}_{3}$ and $\mathrm{FeSiO}_{3}$ triangular diagram (Figure 5(b)) according to Deer et al. (1992) [19] the clino-pyroxene fall in Fe-augite field. On $\mathrm{TiO}_{2}$ vs. $\mathrm{Al}_{2} \mathrm{O}_{3}$ diagram (Figure 5(c)) according to Le Bas (1962) [20] the studied clino-pyroxene plotted in Tholeitic + Calc-alkline figure.

\subsubsection{Amphiboles (Hornblende)}

The mineral analyses for the hornblende are given in Table 4(b), which shows that some hornblende crystals are rich in $\mathrm{CaO}$ and other rich in $\mathrm{Na}_{2} \mathrm{O}$, except one sample with high $\mathrm{TiO}_{2}$ content (3.62 wt\%). Basta (1988) [21] indicated that the primary hornblende in the younger gabbros of Sinai are rich in $\mathrm{TiO}_{2}(>1.5 \%)$ while the secondary hornblende is poor in $\mathrm{TiO}_{2}$.

On Si vs. (Na + Ka) diagram (Figure 5(d)) according to Leak (1978) [22], the majority of samples plot in the ferroan pargastic hornblende field and one sample plot in tschermakitic field.

\subsubsection{Plagioclases}

Plagioclase is ubiquitous mineral in all the studied samples. The mineral compositions are given in Table 4(c). Or-Ab-An ternary diagram (Figure 5(e)) according to Deer et al. (1992) [19] shows that the studied plagioclase analyses plot in the labradorite (An 63) and bytownite (An 76) fields.

In conclusion the gabbro of the studied area are pertain to the Egyptian younger gabbros (Takla et al., 1981 [3]) because they contains fresh pyroxene, brown hornblende and fresh plagioclase. The younger gabbro of the studied area is produced from calc-alkaline magma in continental setting similar to the younger gabbros of Samut-Atud (El Mansi, 1996) [6].

\section{Conclusions}

The study of the younger gabbros in wadi Shianite area is classifieds into: pyroxene hornblende gabbronorite, 


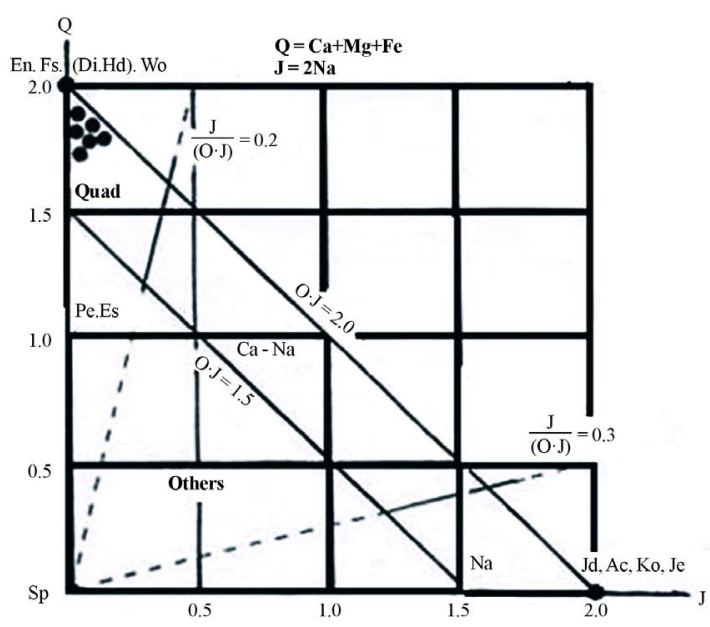

(a)

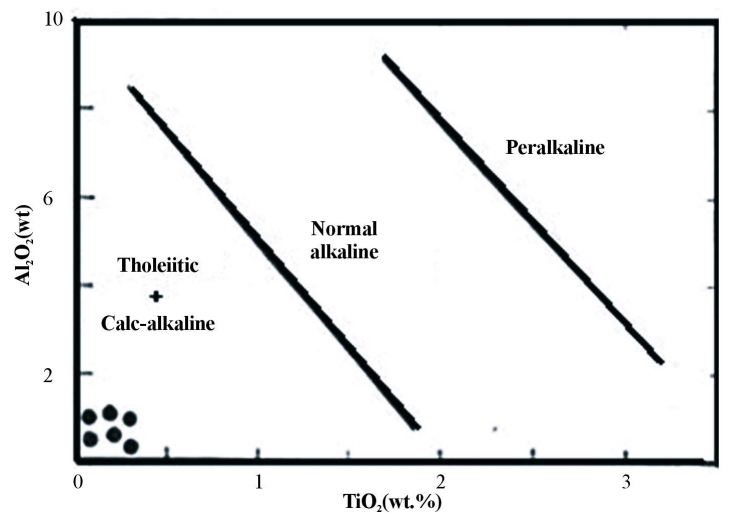

(c)

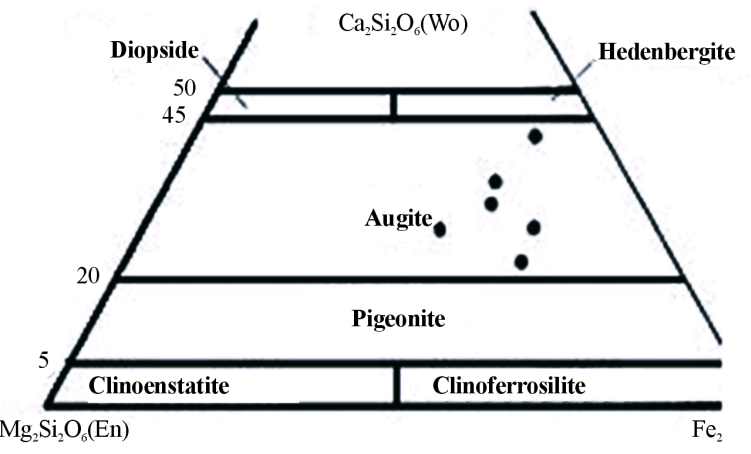

(b)

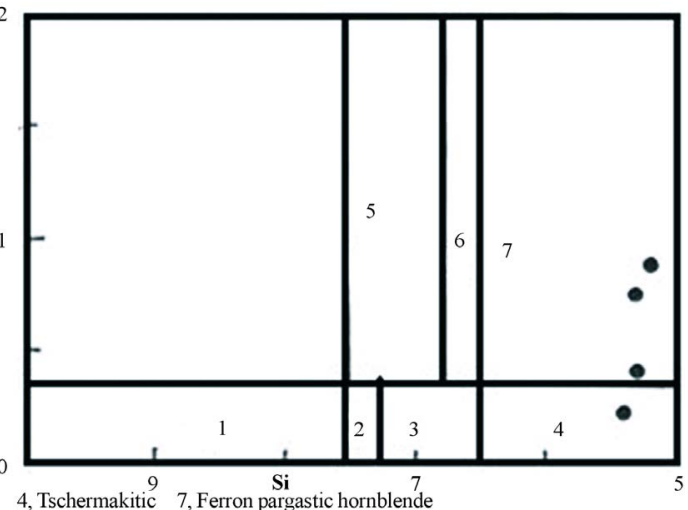

(d)

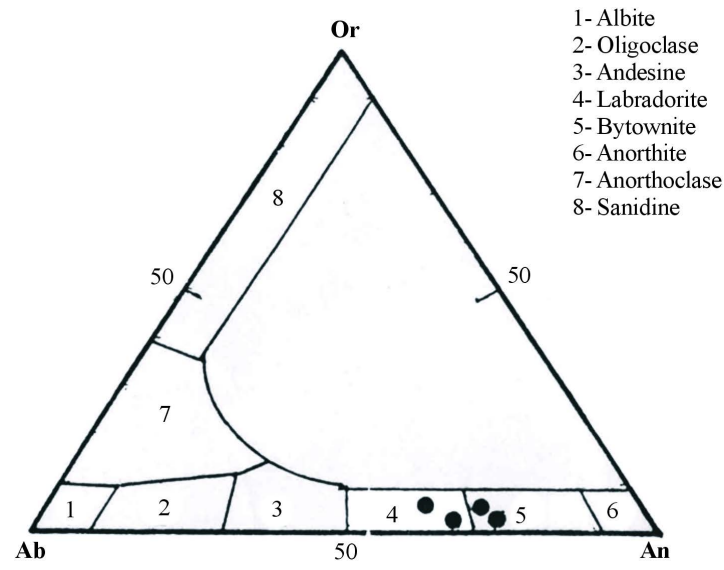

(e)

Figure 5. Mineral analyses of selected mineral phase of the younger gabbros. (a) Q-J diagram (Morimoto et al. 1988); (b) $\mathrm{CaSiO}_{3}-\mathrm{MgSiO}_{3}-\mathrm{FeSiO}_{3}$ diagram (Deer et al. 1992); (c) $\mathrm{Al}_{2} \mathrm{O}_{3}-\mathrm{TiO}_{2}$ diagram (La Bas, 1962); (d) $\mathrm{Si}-$ (Na + K) digram ( Leak, 1978); (e) Or-Ab-An diagrame (Deer et al. 1992).

hornblende gabbro and anorthosite. Pyroxene hornblende gabbronorite is the predominant type; it has hypidiomorphic granular texture and less common porphyritic texture. It consists of plagioclases, pyroxenes (hypersthenes and augite), brown hornblende and biotite. Hornblende gabbro is a coarse to medium grained rock com- 
posed of plagioclase, brown hornblende and biotite. Opaque and apatite are accessories. Anorthosite is idiomorphic and granular. It is composed mainly of plagioclase and diallage.

From the study of the opaque mineralogy it is cleared that the opaque minerals in the younger gabbros range from $1 \%$ to $11 \%$. They are composed mainly of ilmenite and magnetite. The opaque minerals indicate that they are belonging to younger gabbros of Egypt (Takla, 1971 [1]; and Basta and Takla, 1974) [2].

Geochemically, the studied gabbros are similar to the younger gabbros of Egypt (Takla et al., 1981 [3]). They are sub alkaline formed in a continental arc setting. The pyroxene chemistry (augite) indicates that the host rocks are sub alkaline similar to conclusion reached from the whole-rock geochemistry.

\section{References}

[1] Takla, M.A. (1971) Ore Mineralogical and Geochemical Studies of Some Basic and Associating Ultra Basic Igneous Rocks, Eastern Desert, Egypt. Ph.D. Thesis, Faculty of Science, Cairo University, 683 p.

[2] Basta, E.Z and Takla, M.A. (1974) Distribution of Opaque Minerals and the Origin of Gabbroic Rocks of Egypt. Bull. Fac. Sci., Cairo Univ., 47, 346-364.

[3] Takla, M.A., Basta, E.F. and Fawzi, E. (1981) Characterization of the Older and Younger Gabbros of Egypt. Delta. Tanta Univ., 5, 79-314.

[4] Ghoneim, M.F., Aly, S.M., Abd El Tawab, M. and El Baraga, M.H. (1991) Geological Evolution of the Madsus Areaz, Southeast Sinai Peninsula, Egypt. Ann. Geol. Surv., Egypt, 17, 67-71.

[5] Akaad, M.K. and Noweir, A.M. (1980): Geology and Lithostratigraphy of the Arabian Desert Orogenic Belt of Egypt Between Lat. 2535 and 26 30. Bull. Inst Appl. Geol. King Abdel Aaziz (Jaddah), 3, 127-136.

[6] El Mansi, M.M. (1996) Petrology, Radioactivity and Mineralogy of Samut-Aiude Area, Central Eastern Desert, Egypt. Ph.D. Thesis, Cairo University, 301 p.

[7] Mohamed, F.H. and Hassan, M.A. (1996) Geochemical Evolution of Arc-Related Mafic Magmatism at Hmm Naggat District, Eastern Desert of Egypt. Journal of African Earth Sciences, 22, 29-42. http://dx.doi.org/10.1016/0899-5362(96)00018-8

[8] El Gaby, S., List, F.K. and Tehrani, R. (1988) Geology Evolution and Metallogenesis of the Pan African Belt in Egypt. In: El Gaby, S. and Greiling, R.O., Eds., The Pan African Belt of Northeast Africa and Adjacent Aeas, Viewing, Berlin, 17-70.

[9] Takla, M.A. (2002) Classification and Characterization of the Shield Rocks of Egypt. 6th International Conference on the Geology of Arab World, Cairo University, Cairo, Abstracts, xxxii.

[10] Streckeisen, A.L. (1976) Classification and Nomenclature of Igneous Rocks. N. Jahrb. Miner. Abh., 107, 144-240.

[11] Hamimi, Z.E.A. (1992) Geological and Structural Studies on Wadi Betan Area, South Eastern Desert, Egypt. Ph.D. Thesis, Cairo University, Giza, 161 p.

[12] Takla, M.A. and Noweir, A.M. (1980) Mineralogy and Mineral Chemistry of the Ultramafic Mass of El Rubshi, Eastern Desert, Egypt. Neues Jahrbuch für Mineralogie Abhandlungen, 40, 17-28.

[13] Wood, D.A., Tarnery, J., Saunder, A.D., Bougault, H., Joron, J.L., Treuil, M. and Cann, J.R. (1975) Geochemistry of Basalts Drilled in the North Atlantic By IPOD Leg 49, Implecation for Mantle Heterogeneity. Earth and Planetary Science Letters, 42, 77-97. http://dx.doi.org/10.1016/0012-821X(79)90192-4

[14] Wilson, M. (1989) Igneous Petrogenesis. A Global Tectonic Approach. Academic-Division of Unwin Hyman Ltd., Landon, $466 \mathrm{p}$.

[15] Winchester, J.A. and Floyd, P.A. (1977) Geochemical Discrimination of Different Magma Series and Their Differentiation Products Using Immobile Elements. Chemical Geology, 20, 325-343. http://dx.doi.org/10.1016/0009-2541(77)90057-2

[16] Miyashiro, A. (1975) Volcanic Rock Series in Island Arcs and Active Continental Margins. American Journal of Science, 274, 321-355. http://dx.doi.org/10.2475/ajs.274.4.321

[17] Pearce, T.H., Gorman, B.E. and Birkett, T.C. (1975) The $\mathrm{TiO}_{2}-\mathrm{K}_{2} \mathrm{O}-\mathrm{P}_{2} \mathrm{O}_{5}$ Diagram, a Method of Discrimination between Oceanic and Non-Oceanic Basalt. Earth and Planetary Science Letters, 24, 419-426. http://dx.doi.org/10.1016/0012-821X(75)90149-1

[18] Morimoto, N.J., Fabries, A.K., Ferguson, I.A., Ginzburg, M., Ross, A.G., Seifert, F.A. and Zussman, J. (1988) Nomenclature of Pyroxene. Mineralogical Magazine, 52, 535-555. http://dx.doi.org/10.1180/minmag.1988.052.367.15

[19] Deer, W.A., Howie, R.A. and Zussuman, J. (1992) An Introduction to the Rock Forming Minerals. Longman, Landon, $621 \mathrm{p}$.

[20] Le Bas, M.J. (1962) The Caledonian Granites and Diorites of England and Wales. In, Sutherland, D.S., Ed., Igneous 
Rocks of the British Isles, Wiley, Chichester, 191-201.

[21] Basta, F.F. (1988) Mineralogy and Petrology of Some Gabbroic Intrusions in Sinai and the Eastern Desert, Egypt. Annals of the Geological Survey of Egypt, 21, 238-171.

[22] Leake, B.F. (1978) Nomenclature of Amphiboles Amer. Mineralogical Magazine, 63, 1023-1052. 